\title{
Bidentate Schiff bases derived from $(S)$ - $\alpha$-methylbenzylamine as chiral ligands in the electronically controlled asymmetric addition of diethylzinc to aldehydes
}

\author{
Magdalena Jaworska, ${ }^{\text {a* }}$ Mirosław Wełniak, ${ }^{\text {a Justyna Zięciak, }{ }^{\mathrm{b}} \text { Anna Kozakiewicz, }}$ \\ and Andrzej Wojtczak ${ }^{b}$
}

${ }^{a}$ Department of Organic Chemistry, Nicolaus Copernicus University, Gagarina 7, 87-100 Toruń, Poland

${ }^{b}$ Department of Crystallochemistry and Biocrystallography, Nicolaus Copernicus University, Gagarina 7, 87-100 Toruń, Poland

E-mail: magdajaworska@vp.pl

\begin{abstract}
A group of bidentate Schiff bases derived from enantiomerically pure $(S)$ - $\alpha$-methylbenzylamine was synthesized. Crystal structure was determined for three compounds. Schiff bases were used as chiral ligands in the asymmetric addition of $\mathrm{Et}_{2} \mathrm{Zn}$ to aldehydes. The obtained enantioselectivity was e.e. $=8-94 \%$ depending on the substrate and the best was observed for (S,E)-2-(1-(1-phenylethylimino)-ethyl)phenol. The enantioselectivity increase was connected with the substituent-induced electronic effects in the substrate molecules. Molecular modeling resulted in the models of the 3D structures of $\mathrm{Zn}-\mathrm{Zn}$ complex catalysts containing investigated Schiff bases, which were consistent with the reported chirality of the addition product and explained observed e.e. The presented transition state models allow explaining the change of the absolute configuration of diethylzinc addition product in the case of using ortho-substituted aldehydes.
\end{abstract}

Keywords: Bidentate Schiff bases, diethylzinc addition, $\alpha$-methylbenzylamine derivatives, electronic effects

\section{Introduction}

Bidentate chiral salicylidene Schiff bases (SB) derived from $(S)$ - $\alpha$-methylbenzylamine have been of particular interest due to: significant ability of chelation and great stability of metal complexes $^{1}$, interesting antifungal activity $^{2}$ and potential use as important intermediates in the synthesis of benzoxazines having antimicrobial ${ }^{3}$, antitumour ${ }^{4}$ or anthelmintic ${ }^{5}$ activities. $^{2}$ Moreover, enantiopure Schiff bases, after chelation with appropriate metals, have been used as 
catalysts in such reactions as: cyclopropanation of styrene $^{6}$, trimethylsilylcyanation of aldehydes $^{7}$, Heck or Suzuki coupling reactions ${ }^{8}$. These reactions belong to the group of processes of catalytic asymmetric carbon-carbon bond formation, which is one of the most extensively applied methods in organic chemistry. The use of chiral Schiff bases in the asymmetric synthesis was broadly described in literature ${ }^{9}$. However, only few examples of very effective imines have been presented ${ }^{10}$. Bidentate salicylidene $S B$, obtained from $(S)$ - $\alpha$-methylbenzylamine and its derivatives, can be prepared by solvent-free methods ${ }^{11}$ and can also be used to obtain efficient aminophenol ligands for the enantioselective addition reactions ${ }^{12}$.

Enantioselectivity of catalytic asymmetric reactions has usually been coupled to the steric hindrance effects. By contrast, a concept of electronic control or electronic tuning in the asymmetric catalysis reactions has been less explored and is still poorly understood. This effect was previously described e.g. by Landis et al. ${ }^{13}$ in the asymmetric hydrogenation or by Park ${ }^{14}$ in the cyclopropanation of alkenes. Zhang et al. ${ }^{15}$ for the first time observed that the enantioselectivity of diethylzinc addition to aldehydes could depend on the electronic effects related to the nature of the aryl aldehydes and increases with more reactive substrates. In this article we report the synthesis of nine Schiff bases derived from $(S)$ - $\alpha$-methylbenzylamine and their efficiency as chiral ligands. Also, the remarkable findings about electronic effects in the asymmetric addition of diethylzinc to aldehydes are reported.

\section{Results and Discussion}

Schiff bases (1-9) have been obtained from $(S)$ - $\alpha$-methylbenzylamine in the reaction with respective aromatic aldehydes or ketones with 46-99\% yields (Scheme 1). Reactions were performed in toluene according to the procedure reported by Iglesias ${ }^{6}$.

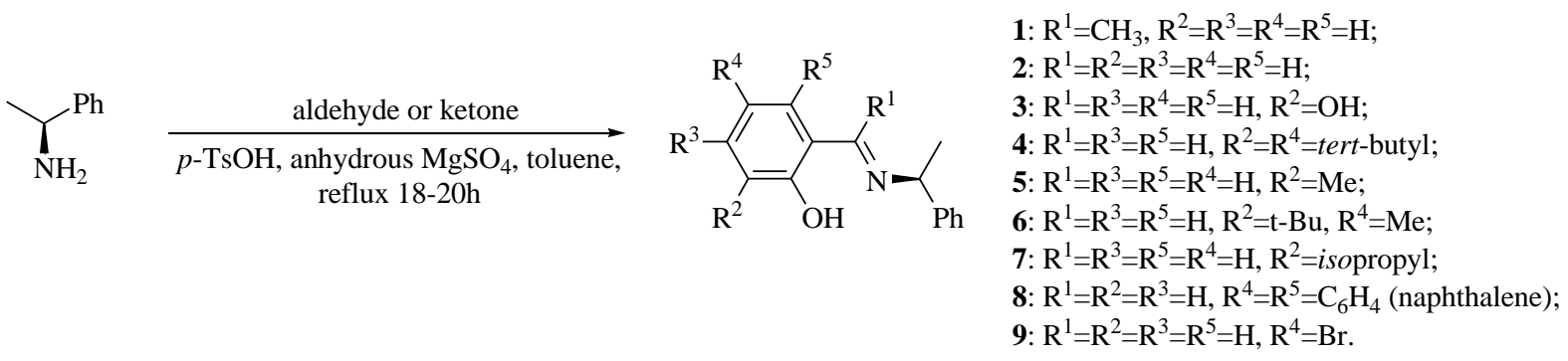

Scheme 1. Synthesis of Schiff base ligands 1-9.

All products have been purified by crystallization from appropriate solvents $(\mathbf{2 - 4 , 8 , 9 )}$ or by distillation under reduced pressure $(\mathbf{1}, \mathbf{5 - 7})$. The compounds similar to ours $\mathbf{1}, \mathbf{2}, \mathbf{4}, \mathbf{8}$ and 9 have been previously described in Ref. 6,7,16 and 17. The detailed analysis revealed that our compounds have already been synthesized as the same enantiomers $(\mathbf{2}, \mathbf{4}, \mathbf{8})^{6,7}$, or as $R$ enantiomers $(\mathbf{1}, \mathbf{9})^{16,17}$ while all our compounds have $S$-configuration. Comparison of our results 
with the above references showed that there are some differences between the results of the optical rotation measurements in the case of $\mathbf{1}, \mathbf{2}, \mathbf{4}, \mathbf{8}, \mathbf{9}$. The discrepancy could be caused by: the use of the different solvent for the measurement ${ }^{6,16,17}$ for $\mathbf{2 , 4 , 8}$, different enantiomeric purity of $\alpha$-methylbenzylamine ${ }^{17}$ for $\mathbf{9}$, or a lack of the Schiff base 1 purification ${ }^{16}$. All SB described here were of high purity that was confirmed by the MS analyses.

The UV-Vis absorption spectra were also recorded for all obtained Schiff bases (methanol solutions). Results are presented on Figure 1.

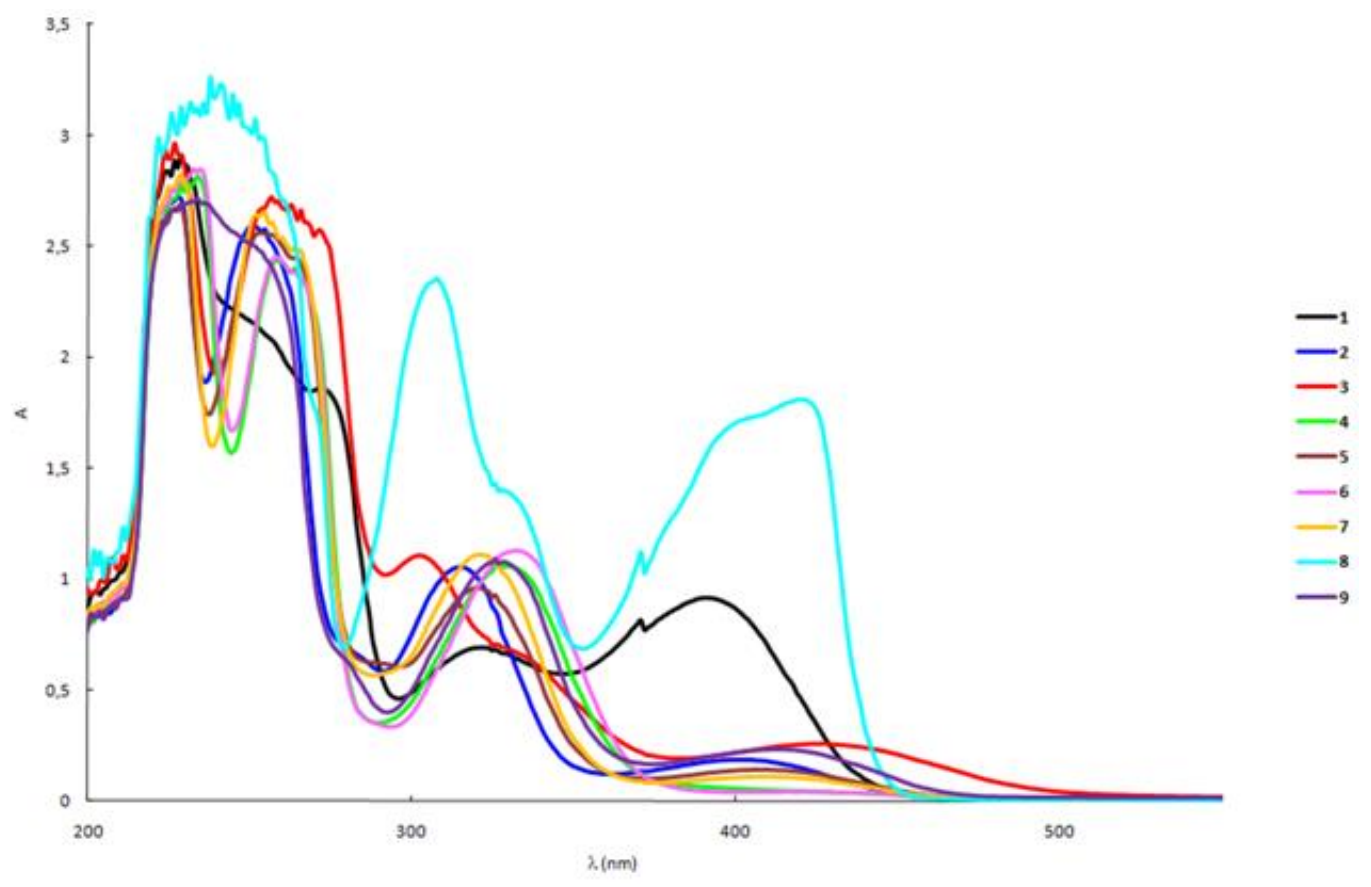

Figure 1. The absorption UV-Vis spectra of Schiff bases 1-9 in methanol solutions $\left(\mathrm{c}=2.510^{-5} \mathrm{M}\right)$.

The solution spectra indicated that the electronic properties of SB 1-9 were strongly dominated by the donor-acceptor chromophore (Fig. 1). Electronic absorption spectra of Schiff bases showed the $\pi \rightarrow \pi^{*}$ transitions related to aromatic rings at about 205-250 nm and $\pi \rightarrow \pi^{*}$ transitions related to imine group at about 275-350 $\mathrm{nm}$. Moreover, the longer wavelength band at 325-450 nm, characteristic for $\mathbf{1}$ and 8, was assigned in accordance with Ref. 18 and 19 to an intramolecular charge transfer involving the whole molecule. This effect could be caused by the probable keto-amine tautomer formation in a methanol solution. The tautomerization of chiral hydroxy SB was described before ${ }^{20}$ and usually is connected with an intra- and intermolecular hydrogen bond between phenolic hydroxyl and iminium nitrogen.

The crystal structures for imines $\mathbf{2 , 8}$ and $\mathbf{9}$ have been determined by the X-ray analysis. Details of the diffraction experiments and structure refinement are presented in Table 1. 
Table 1. Crystal data and structure refinement for $\mathbf{2 , 8}$ and 9

\begin{tabular}{|c|c|c|c|}
\hline & 2 & 8 & 9 \\
\hline Empirical formula & $\mathrm{C}_{15} \mathrm{H}_{15} \mathrm{NO}$ & $\mathrm{C}_{19} \mathrm{H}_{17} \mathrm{NO}$ & $\mathrm{C}_{15} \mathrm{H}_{14} \mathrm{BrNO}$ \\
\hline Formula weight & 225.28 & 275.34 & 304.18 \\
\hline Crystal system, space group & Monoclinic, C2 & Monoclinic, $\mathrm{P} 22_{1}$ & Monoclinic, C2 \\
\hline Unit cell dimensions $\left(\AA{ }^{\circ}{ }^{\circ}\right)$ & $a=18.533(3)$ & $\mathrm{a}=8.8834(11)$ & $a=20.890(4)$ \\
\hline & $b=5.9018(3)$ & $\mathrm{b}=5.7689(9)$ & $b=5.7721(8)$ \\
\hline & $c=14.803(2)$ & $c=14.698(2)$ & $c=14.5690(15)$ \\
\hline & $\beta=129.42(2)$ & $\beta=102.399(11)$ & $\beta=129.030(10)$ \\
\hline Volume $\left(\AA^{3}\right)$ & $1250.8(3)$ & 735.67(18) & $1364.6(4)$ \\
\hline $\mathrm{Z}$, Calculated density $\left(\mathrm{Mg} / \mathrm{m}^{3}\right)$ & 4, 1.196 & $2,1.243$ & $4,1.481$ \\
\hline $\begin{array}{l}\text { Absorption coefficient } \\
\left(\mathrm{mm}^{-1}\right)\end{array}$ & 0.075 & 0.076 & 3.000 \\
\hline $\mathrm{F}(000)$ & 480 & 292 & 616 \\
\hline Crystal size (mm) & $0.39 \times 0.31 \times 0.08$ & $0.71 \times 0.13 \times 0.09$ & $0.67 \times 0.24 \times 0.14$ \\
\hline $\begin{array}{l}\text { Theta range for data collection } \\
\left({ }^{\circ}\right)\end{array}$ & 2.20 to 26.00 & 2.47 to 27.00 & 2.51 to 31.38 \\
\hline Reflections collected / unique, & $4015 / 2168$ & $5864 / 2553$ & $6801 / 2775$ \\
\hline $\mathrm{R}$ (int) & $\mathrm{R}($ int $)=0.0222$ & $\mathrm{R}($ int $)=0.0778$ & $\mathrm{R}($ int $)=0.0509$ \\
\hline Completeness, $\theta \max$ & $99.9 \%, 26.00$ & $99.8 \%, 27.00$ & $99.9 \%, 26.00$ \\
\hline Max. and min. transmission & $0.9937 / 0.9712$ & $0.9929 / 0.9480$ & $0.6800 / 0.2387$ \\
\hline Data / restraints / parameters & $2168 / 1 / 154$ & $2553 / 1 / 190$ & $2775 / 1 / 163$ \\
\hline Goodness-of-fit on $\mathrm{F}^{2}$ & 0.890 & 1.006 & 1.038 \\
\hline Final $R$ indices $[I>2 \sigma(I)]$ & $\begin{array}{c}\mathrm{R} 1=0.0354 \\
\mathrm{wR} 2=0.0848\end{array}$ & $\begin{aligned} \mathrm{R} 1= & 0.0647, \mathrm{wR} 2 \\
= & 0.1634\end{aligned}$ & $\begin{array}{c}\mathrm{R} 1=0.0384 \\
\mathrm{wR} 2=0.0884\end{array}$ \\
\hline $\mathrm{R}$ indices (all data) & $\begin{array}{c}\mathrm{R} 1=0.0529 \\
\mathrm{wR} 2=0.0920\end{array}$ & $\begin{array}{c}\mathrm{R} 1=0.0983 \\
\mathrm{wR} 2=0.1834\end{array}$ & $\begin{array}{l}\mathrm{R} 1=0.0558 \\
\mathrm{wR} 2=0.0965\end{array}$ \\
\hline Absolute structure parameter & $-0.1(18)$ & $2(3)$ & $-0.001(13)$ \\
\hline Largest diff. peak/hole e. $\mathrm{A}^{-3}$ & $0.114 /-0.099$ & $0.167 /-0.178$ & $0.225 /-0.570$ \\
\hline
\end{tabular}

The molecular structure of $\mathbf{2 , 8}$ and $\mathbf{9}$ with the atom numbering scheme is presented on Fig. 2.

The molecular conformation of all investigated compounds $\mathbf{2}, \mathbf{8}$ and $\mathbf{9}$ was determined by almost identical intramolecular hydrogen bonds between $\mathrm{O} 1$ hydroxyl group and the imine N1 atom. The presence of the intramolecular O-H...N hydrogen bond was detected in all structures of analogous imines as found with the $\mathrm{CSD}^{21}$. In all reported structures $\mathbf{2 , 8}$ and 9 the molecule had the $E$-conformation. 
A)

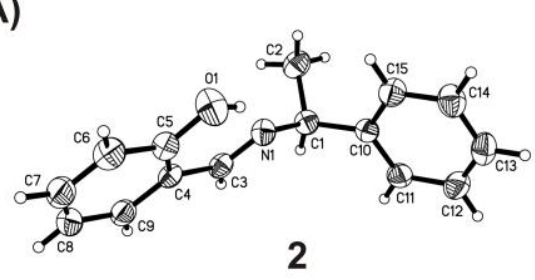

B)

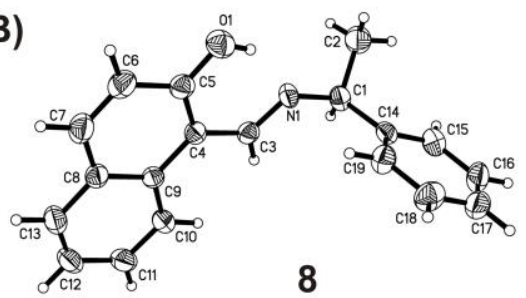

C)

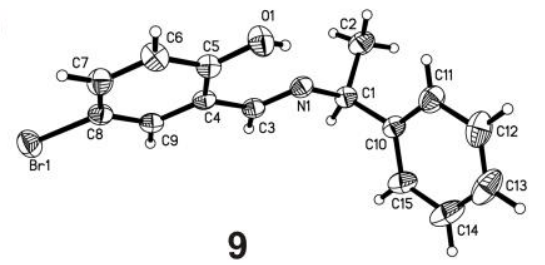

Figure 2. Molecule of A) 2, B) 8, C) 9. The thermal ellipsoids are plotted at $30 \%$ probability level.

The presence of bromine atom in $\mathbf{9}$ allowed determining the absolute configuration as $S$ which was consistent with the chirality of the substrate used in the synthesis. For $\mathbf{2}$ and $\mathbf{8}$, the absolute structure could not be determined reliably with the Flack method ${ }^{22}$. Therefore, the correct chirality was chosen as $S$ by the comparison to that determined for 9 .

The inspection of CSD revealed the report on the crystal structure of $R$-enantiomer of $\mathbf{9}^{23}$. Comparison of the structure 9 with that reported for $R$-enantiomer showed that the cell parameters of our structure were of higher precision and the structure determination resulted in the $\mathrm{R}$ value lower by $1 \%$. However, some differences in the molecular conformation were found which reflected the opposite configuration on $\mathrm{C} 1$. The structure of $S$-enantiomer reported here was similar to that of $S$-enantiomer of the chloro- $\operatorname{analog}^{24}$, for which the two torsion angles described above are 120.7 and $48.2^{\circ}$.

We determined the structure of $\mathbf{2}$, to obtain the reference structure of the compound with no additional substituent in the phenolic ring. The CSD search revealed the report on the racemate of $\mathbf{2}$ crystallizing in the P2(1)/n space group and the optically pure form crystallizing in the C2 space group ${ }^{25}$.

SB (1-9) were tested as chiral ligands in the enantioselective addition of diethylzinc to aldehydes (Scheme 2).

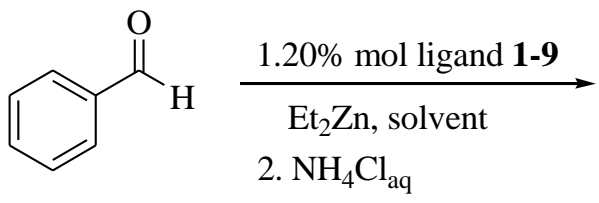<smiles>CC[C@@H](O)c1ccccc1</smiles>

Scheme 2. Asymmetric addition of diethylzinc to benzaldehyde. 
In the first stage, ligands (1-9) were used in an amount of $20 \mathrm{~mol} \%$. Diethylzinc in amount of 2 equiv. in relation to 1 equiv. of benzaldehyde was used according to procedures described before in Ref. 26. Previous reports 27 and 28 showed that the enantioselectivity depends on temperature during the catalyst formation. Therefore, different temperature values were examined for the first step of reaction. All results of studied reactions are summarized in Table 2.

Table 2. Addition of diethylzinc to benzaldehyde in a presence of catalysts containing the Schiff bases 1-9

\begin{tabular}{|c|c|c|c|c|c|}
\hline Entry & Ligand & Time (h) & Yield of by-product $(\%)^{\mathrm{d}}$ & $\begin{array}{c}\text { Yield } \\
(\%)^{\mathrm{e}}\end{array}$ & E.e. $(\%)^{\mathrm{f}} /$ config. ${ }^{\mathrm{g}}$ \\
\hline 1 & 1 & $24^{\mathrm{a}}$ & 22 & 74 & $27(S)$ \\
\hline 2 & 1 & $24^{\mathrm{b}}$ & 20 & 59 & $27(S)$ \\
\hline 3 & 1 & $24^{\mathrm{c}}$ & 14 & 79 & $8(S)$ \\
\hline 4 & 2 & 24 & - & $>99$ & $18(S)$ \\
\hline 5 & 3 & 24 & 10 & 41 & - \\
\hline 6 & 4 & 24 & 13 & 64 & $12(S)$ \\
\hline 7 & 5 & 24 & 5 & 95 & $18(S)$ \\
\hline 8 & 6 & 24 & 8 & 66 & $8(S)$ \\
\hline 9 & 7 & 24 & 5 & 95 & $18(S)$ \\
\hline 10 & 8 & 24 & 5 & 95 & $8(S)$ \\
\hline 11 & 9 & 24 & 9 & 41 & $16(S)$ \\
\hline
\end{tabular}

${ }^{a}$ Reaction was carried at the temperature range from $0{ }^{\circ} \mathrm{C}$ to $+20^{\circ} \mathrm{C}$. ${ }^{b}$ Reaction was carried at the temperature range from $-20^{\circ} \mathrm{C}$ to $+20^{\circ} \mathrm{C}$. ${ }^{c}$ Reaction was carried at the temperature range from $70^{\circ} \mathrm{C}$ to $+20^{\circ} \mathrm{C}$. ${ }^{\mathrm{d}}$ Determined by GC using Zebron ZB-5 capillary column (for crude samples). ${ }^{\mathrm{e}}$ Isolated products. ${ }^{\mathrm{f}}$ Determined by HPLC using OD-H column. ${ }^{\mathrm{g}}$ The configuration was determined by the measurement of the optical rotation and by comparison with literature values $^{29}$.

The best results for investigated SB chiral ligands were observed when both the catalyst formation and addition to benzaldehyde were performed at $0^{\circ} \mathrm{C}$ (then the reaction was carried at $20^{\circ} \mathrm{C}$ ). The absolute configuration of the product depended on the absolute configuration of the used SB ligand. The obtained results indicated that bidentate ligands (1-9) having the $S$ configuration gave $(S)$-1-phenylpropanol as a major product, but only with a weak asymmetric induction in the investigated process. However, relatively good yields of product (41-99\%) and poor yields of by-product $(<22 \%)$ have been achieved.

The modest enantiomeric excesses in the addition $\mathrm{Et}_{2} \mathrm{Zn}$ to benzaldehyde, e.e. $=8-27 \%$ were obtained. The highest enantiomeric excess was observed for ligand 1 (Table 2: entry 1). The results showed that the presence of the methyl moiety ( $\mathrm{R}^{1}$ substituent, Scheme 1), bonded to imine group was a discriminating factor for the substrate orientation. Similar effects of the 
methyl substituent on the imine carbon atom for Schiff base ligands derived from 4hydroxy[2.2]paracyclophane were reported by Danilova et al. ${ }^{30}$.

Based on the crystal structure of $\mathbf{2}$, models of the active complex with ligand $\mathbf{1}$ having opposite $R$-configuration as well as $S$-configuration were proposed. Both models were optimized by Molecular Mechanics method in Arguslab program using UFF force field ${ }^{31}$ and were consistent with the literature examples for chiral bidentate ligands ${ }^{26,32,33}$. The first model with $(R)-1$ showed that the addition to $R e$ face of the aldehyde was preferred. The bulk of the phenyl ring in the $R$-enantiomer of the ligand enforces binding of benzaldehyde with its $R e$ face exposed to ethyl group addition. Therefore, the obtained models suggested the importance of the absolute configuration of ligand for chirality of the addition product.

The model with $(S)$-1 showed that substituent $\mathrm{R}^{1}=\mathrm{CH}_{3}$ might have only limited effect on the orientation of the substrate although preference for the $S i$ face, which was consistent with observed e.e. $=27 \%$ (Table 2: entry 1) and $S$-configuration of addition product. It was also noticed that replacement of this methyl group by the bigger group could increase the enantiomeric excess due to the increased bulk near the expected position of benzaldehyde (Fig 3). The presence of the substituent in the ligand phenolic ring also decreased the enantiomeric excess, which was probably connected with either bulk or electronic effects of the substituent. However, Fig. 3 showed that the presence of substituents in phenolic ring, even on C6 (see: Fig. 2), had only secondary importance for the stereochemistry of the end product of $\mathrm{Et}_{2} \mathrm{Zn}$ addition to benzaldehyde since they would be positioned too far away from the reaction center in the transition state. Similar effect was described by Parrott $\mathrm{II}^{34}$ and Tanaka ${ }^{35}$.

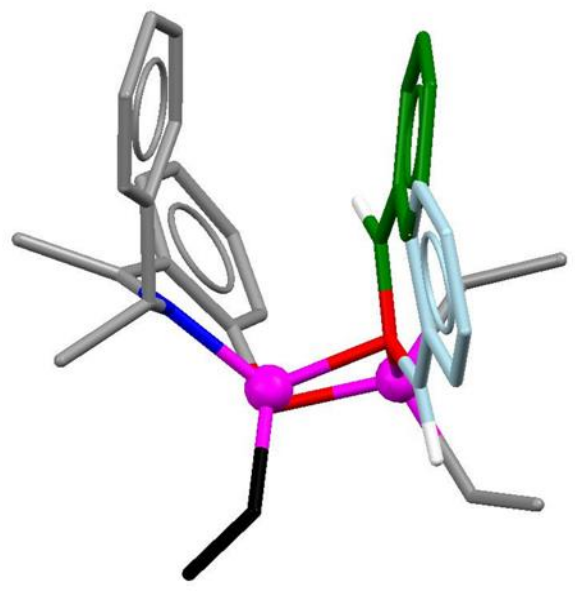

Figure 3. Model of the active complex $\mathrm{Zn}-\mathrm{Zn}$ formed with ligand 1 with the orientation of the substrate as obtained with MM calculations ${ }^{31}$. The addition to $S i$ (green) and $R e$ (cyan) faces are equally possible.

The presented model obtained for ligand $\mathbf{1}$ showed, that there is only a little difference between the addition to Re and $\mathrm{Si}$ faces (Fig. 3). Calculation indicated that in both $\mathrm{Re}$ and $\mathrm{Si}$ orientation of the substrate, the $\pi-\pi$ stacking interactions could stabilize the transition state. Also, 
$\mathrm{R}^{1}$ substituent might be a factor responsible for slight asymmetric induction. This conclusion was consistent with our experimental data indicating that the absence of $-\mathrm{CH}_{3}$ group in other investigated ligands resulted in the decrease of enantioselectivity (Table 2: entries 4-11).

In spite of only modest e.e. $=27 \%$ obtained for ligand 1, the ligand was examined in a series of reactions with a variety of aromatic and aliphatic aldehydes under optimized conditions (Table 3).

Table 3. Addition of diethylzinc to aldehydes catalyzed by the Schiff base $\mathbf{1}$

\begin{tabular}{cccccc}
\hline Entry & Ligand & Aldehyde & $\begin{array}{c}\text { Time } \\
(\mathrm{h})\end{array}$ & $\begin{array}{c}\text { Yield } \\
(\%)^{\mathrm{a}}\end{array}$ & E.e. $(\%)^{\mathrm{b} / \text { config. }^{\mathrm{c}}}$ \\
\hline 1 & $\mathbf{1}$ & $o$-methoxybenzaldehyde & 72 & 38 & $16(R)$ \\
2 & $\mathbf{1}$ & m-methoxybenzaldehyde & 72 & 78 & $23(R)$ \\
3 & $\mathbf{1}$ & $p$-methoxybenzaldehyde & 72 & 61 & $39(S)$ \\
4 & $\mathbf{1}$ & $o$-chlorobenzaldehyde & 72 & 80 & $24(R)$ \\
5 & $\mathbf{1}$ & $o$-bromobenzaldehyde & 72 & 52 & $15(R)$ \\
6 & $\mathbf{1}$ & m-chlorobenzaldehyde & 72 & 92 & $94(S)$ \\
7 & $\mathbf{1}$ & $p$-chlorobenzaldehyde & 72 & 75 & $53(S)$ \\
8 & $\mathbf{1}$ & $p$-bromobenzaldehyde & 72 & 90 & $96(S)$ \\
9 & $\mathbf{1}$ & $p$-dimethylaminobenzaldehyde & 72 & 89 & - \\
10 & $\mathbf{1}$ & cyclohexanecarboaldehyde & 72 & 94 & $30(S)$ \\
\hline
\end{tabular}

${ }^{a}$ Isolated products. ${ }^{b}$ Determined by HPLC using OD-H column or by GC using $\beta$-Dex capillary column. ${ }^{\mathrm{c}}$ The configuration was determined by the measurement of the optical rotation and by comparison to literature values ${ }^{29}$.

When $o$-, $m$-, $p$-methoxy-, $p$-dimethylamino, $o$-chloro-, $o$-bromobenzaldehyde and also cyclohexanecarbaldehyde (Table 3: entries 1-5, 9-10) were used, the enantiomeric excesses were lower or at the same level as for benzaldehyde (Table 2: entry 1). However, in the case of $m$ chloro and $p$-chlorobenzaldehyde as well as $p$-bromobenzaldehyde the e.e.'s of addition products were significantly higher (e.e. $=94 \%, 53 \%$ and 96\%) (Table 3: entries 6-8). The presence of electron-withdrawing substituents in substrates, that caused an increase of Lewis acidity on the carbon atom of carbonyl group, was responsible for increasing reactivity of the substrate. Zhang $^{15}$ reported the linear relation between enantioselectivity and the Hammett constant for para-substituted substrates using pyridylphenols as ligands. In contrast, in our group of ligands such linear dependence was not so clear. In some reports e.g. Ref. 36 about the electronic effects in the organic reactions, the reasons of this phenomenon were inadequately described. In accordance with mechanism proposed by Zhang ${ }^{15}$ for diethylzinc addition and Landis ${ }^{13}$ for asymmetric hydrogenation, the aldehyde binding to zinc complex with Schiff base ligand, involved in the salicylidene moiety the imine bond conjugated with the aromatic ring, led to the formation of transition state that was stabilized by the electron-withdrawing substituents on 
para- position. The UV-Vis spectra (Fig. 1) described above revealed the tautomeric equilibrium for the analyzed Schiff base 1. The tautomerization effect probably also affected the interaction between the substrate and the ligand as well as the geometry of the catalyst complex and the transition state (Fig. 3). The appropriate molecular calculation studies are currently in progress also for other SB ligands ${ }^{37}$. The tautomerization of Schiff bases was described in literature and is important phenomenon for understanding many physicochemical properties, such as photo- and thermochromism as well as the biological activity ${ }^{38}$.

For aldehydes with ortho- substituents and for $m$-methoxybenzaldehyde, the change from $S$ to $R$ configuration of the addition product was observed. The $R e$ face of the ethyl group addition seems to be stabilized by the $\pi-\pi$ interaction between the substrate and the ligand rings as well as the electrostatic interactions between the aldehyde $\mathrm{H}$ atom and the imine moiety (Fig. 3). However, these effects give no significant e.e. for the major $R$-product (Table 3). The bulk of investigated ortho substituents probably had some influence on the absolute configuration of the product.

The use of diethylzinc addition reaction for the stereoselective synthesis of biologically active compounds is very extensive. Schiff base chiral ligands described in this paper are also during investigation for the application in the synthesis of formoterol ${ }^{39}$ derivatives that are possible $\beta_{2}$-adrenergic receptor agonists.

\section{Conclusions}

Nine bidentate Schiff bases were synthesized from enantiomerically pure $(S)$ - $\alpha$ methylbenzylamine and were used as chiral ligands in the addition of $\mathrm{Et}_{2} \mathrm{Zn}$ to various aldehydes. Due to the characteristic steric position of methyl group in $(S, E)-2-(1-(1-$ phenylethylimino)ethyl)phenol 1 this ligand promoted the formation of (S)-1-aryl-1-propanol as a predominant product. The average enantiomeric excess was e.e. $=27 \%$ for benzaldehyde as a substrate. The increase up to e.e. $=94 \%$ and $96 \%$ found for $m$-chlorobenzaldehyde and $p$ bromobenzaldehyde, respectively, was a consequence of the increased Lewis acidity of the carbon atom of the carbonyl group. The probable formation of keto-amine tautomer of $\mathbf{1}$ observed on the UV-Vis spectra also affected the enantioselectivity. Moreover, the observed change of the absolute configuration of $\mathrm{Et}_{2} \mathrm{Zn}$ addition products could be related to the $\pi-\pi$ stacking efects between aromatic rings of the substrate with ortho- or meta-substituents and the ligand as well as to some electrostatic interactions near the imine moiety. 


\section{Acknowledgements}

The research was supported by the Nicolaus Copernicus University grant UMK 526-CH. The authors also thank Ewelina Drabik, M. Sc. from Centre of Molecular and Macromolecular Studies, Polish Academy of Science, Łódź for help during the mass spectrometry experiments.

\section{Experimental Section}

General. Melting points were determined by a Büchi apparatus in open capillaries and are uncorrected. Optical rotations were measured on PolAAr 3000 automatic polarimeter in a $10 \mathrm{~cm}$ cell at $589 \mathrm{~nm}$. Elemental analyses were performed on an Elementary Analysensysteme GmbH Vario MACRO CHN analyzer. The ${ }^{1} \mathrm{H}$ and ${ }^{13} \mathrm{C}$ NMR spectra were recorded on Varian Gemini 200 multinuclear instrument and on Bruker Avance $300 \mathrm{MHz}$ instrument respectively, in $\mathrm{CDCl}_{3}$ at ambient temperature. Chemical shifts were reported in parts per million ( $\delta$ scale), coupling constants ( $\mathrm{J}$ values) were listed in Hertz. UV-Vis spectra were recorded on Helios UNICAM in quartz cuvettes. Infrared spectra were reported in reciprocal centimeters $\left(\mathrm{cm}^{-1}\right)$ and were measured as a nujol mull or as a neat. EI-HRMS and MS(EI) experiments were performed on Finigan MAT 95 (Bremen, Germany) by Environmental Laboratory of Organic Compounds and Polymer Analysis, Centre of Molecular and Macromolecular Studies, Polish Academy of Science, Łódź. GC was performed on a Perkin-Elmer AutoSystem XL chromatograph using $\beta$ Dex 325 capillary column $(30 \mathrm{~m}, 0.25 \mathrm{~mm})$, or on Shimadzu GC-14A using Zebron ZB-5 capillary column. HPLC analyses were performed on a Shimadzu LC-10AT chromatograph using Chiralcel OD-H column $(250 \times 4.6 \mathrm{~mm})$. Yellow crystals of $\mathbf{2 , 8}$ and $\mathbf{9}$ have been obtained from the hexane-ethyl acetate solution. The X-ray data were collected at 292(2) K with an Oxford Sapphire CCD diffractometer using MoK $\alpha$ radiation $\lambda=0.71073 \AA$ and $\omega-2 \theta$ method. The numerical absorption correction was applied with CrysAlis171 package of programs, Oxford Diffraction, $2000^{40}$. Structures were solved by direct methods and refined with the full-matrix least-squares method on $\mathrm{F}^{2}$ with the use of SHELX-97 program package ${ }^{41}$. The hydrogen atoms have been located from the difference electron density maps and constrained during refinement. The absolute configuration for 9 was determined by the Flack method ${ }^{22}$ and verified with the prior knowledge on the chirality on $\mathrm{C} 1$ of the used substrate. Since the method of synthesis had not inverted the chirality of the existing center, the absolute structure for $\mathbf{2}$ and $\mathbf{8}$ was determined by comparison with that of $\mathbf{9}$. For all investigated compounds, the $(1 S)$ configuration was assigned.

The structural data have been deposited with Cambridge Crystallographic Data Centre, the CCDC numbers 782015,782016 and 782014 for $\mathbf{2 , 8}$ and $\mathbf{9}$, respectively.

Materials. TLC was performed on silica gel Polygram ${ }^{\circledR}$ Sil G/UV 254 (0.2mm). Regular column chromatography was carried out using Silica Gel 60 (0.06-0.2mm). All solvents were purchased 
from POCh Gliwice, Poland. Toluene was distilled from sodium prior to use. Diethylzinc, $(S)-\alpha-$ methylbenzylamine (e.e.=99\%), aldehydes were purchased from Sigma-Aldrich or Fluka. 3,5Di-tert-butyl-2-hydroxybenzaldehyde, 3-tert-butyl-5-methyl-2-hydroxybenzaldehyde, 2hydroxy-3-methylbenzaldehyde and 2-hydroxy-3-isopropylbenzaldehyde were obtained according to literature procedures ${ }^{42,43}$.

\section{Preparation of Schiff bases 1-9}

A 100-ml round-bottom flask equipped with a magnetic stirring bar and reflux condenser was filled with $8.25 \mathrm{mmol}(1.0 \mathrm{~g})$ of $(S)$ - $\alpha$-methylbenzylamine, $60 \mathrm{ml}$ of anhydrous toluene, 8.25 mmol of appropriate aldehydes (or ketone), $20 \mathrm{mg}$ of $p$-toluenesulphonic acid and $6.0 \mathrm{~g}$ of anhydrous $\mathrm{MgSO}_{4}$. The reaction mixture was stirred for $18-20 \mathrm{~h}$ at reflux and then, after cooling to room temperature, it was filtered onto Celite pad of $1 \mathrm{~cm}$ thickness in a fritted glass funnel. The solvent was stripped and the crude product was either crystallized or purified by distillation under reduced pressure. Yields and physical properties are presented below.

(S,E)-2-(1-(1-Phenylethylimino)ethyl)phenol (1). 2-Hydroxyacetophenone as a substrate. Yellow oil (82\%). Purified by distillation under reduced pressure. Bp $175-180^{\circ} \mathrm{C} / 1 \mathrm{Torr},[\alpha]_{\mathrm{D}}{ }^{20}=$ +506 (c 0.70, MeOH) (lit. ${ }^{16} R$-enantiomer without purification: $[\alpha]^{20} \mathrm{D}=-275\left(\mathrm{c} 0.45, \mathrm{CH}_{2} \mathrm{Cl}_{2}\right)$ ). ${ }^{1} \mathrm{H}$ NMR $\left(300 \mathrm{MHz}, \mathrm{CDCl}_{3}\right): \delta 1.65\left(\mathrm{~d}, J=6.6 \mathrm{~Hz}, 3 \mathrm{H}, \mathrm{CH}_{3}\right), 2.35\left(\mathrm{~s}, 3 \mathrm{H}, \mathrm{CH}_{3}\right), 4.95(\mathrm{q}, J=6.6$ $\mathrm{Hz}, 1 \mathrm{H}, \mathrm{CH}), 6.77$ (td, $J=1.2 \mathrm{~Hz}, J=8.1 \mathrm{~Hz}, 1 \mathrm{H}, \mathrm{CH}$-aryl), 6.95 (dd, $J=1.2 \mathrm{~Hz}, J=8.4 \mathrm{~Hz}$, 1H, CH-aryl), 7.22-7.52 (m, 7H, CH-aryl), 16.76 (br s, $1 \mathrm{H}, \mathrm{OH}) .{ }^{13} \mathrm{C} \mathrm{NMR}\left(75.5 \mathrm{MHz}, \mathrm{CDCl}_{3}\right)$ : $\delta 14.63\left(\mathrm{CH}_{3}\right), 25.21\left(\mathrm{CH}_{3}\right), 58.47(\mathrm{CH}), 116.98(\mathrm{CH}), 118.90(\mathrm{CH}), 119.28(\mathrm{C}), 126.29(2 \times \mathrm{CH})$, $127.17(\mathrm{CH}), 128.11(\mathrm{CH}), 128.79(2 \times \mathrm{CH}), 132.61(\mathrm{CH}), 144.14(\mathrm{C}), 164.29(\mathrm{C}), 170.53(\mathrm{C}) . \mathrm{IR}$ (neat): 3028.9, 2971.8, 2554.1, 1613.6, 1578.8, 1503.8, 1449.0, 1375.0, 1303.7, 1257.3, 1161.4, 1133.5, 1085.9, 1014.6, 937.8, 837.1, 754.8, 700.3. MS(EI): $m / z 239[\mathrm{M}]^{+}(69), 135$ (38), 105 (100). EI-HRMS: $m / z,[\mathrm{M}]^{+}$calcd for $\mathrm{C}_{16} \mathrm{H}_{17} \mathrm{NO}, 239.1310$; found: 239.1306 .

(S,E)-2-((1-Phenylethylimino)methyl)phenol (2). 2-Hydroxybenzaldehyde as a substrate. Yellow solid (69\%). Purified by re-crystallization from hexane-ethyl acetate $(1: 1, \mathrm{v} / \mathrm{v})$. Mp 75$77^{\circ} \mathrm{C}$ (lit. $\left.{ }^{6} 72-74^{\circ} \mathrm{C}\right),[\alpha]_{\mathrm{D}}{ }^{20}=+175$ (c 1.15, MeOH) (lit. ${ }^{6}[\alpha]^{20} \mathrm{D}=+159$ (c $\left.0.04, \mathrm{CH}_{2} \mathrm{Cl}_{2}\right)$ ). ${ }^{1} \mathrm{H}$ NMR $\left(300 \mathrm{MHz}, \mathrm{CDCl}_{3}\right): \delta 1.65\left(\mathrm{~d}, J=6.6 \mathrm{~Hz}, 3 \mathrm{H}, \mathrm{CH}_{3}\right), 4.57(\mathrm{q}, J=6.6 \mathrm{~Hz}, 1 \mathrm{H}, \mathrm{CH}), 6.88$ $(\mathrm{td}, J=1.2 \mathrm{~Hz}, J=8.4 \mathrm{~Hz}, 1 \mathrm{H}, \mathrm{CH}$-aryl), 6.98 (d, $J=8.4 \mathrm{~Hz}, 1 \mathrm{H}, \mathrm{CH}-\operatorname{aryl}), 7.23-7.41$ (m, 7H, $\mathrm{CH}$-aryl), $8.42(\mathrm{~s}, 1 \mathrm{H}, \mathrm{HC}=\mathrm{N}), 13.56($ br s, $1 \mathrm{H}, \mathrm{OH}) .{ }^{13} \mathrm{C} \mathrm{NMR}\left(50.3 \mathrm{MHz}, \mathrm{CDCl}_{3}\right): \delta 24.71$ $\left(\mathrm{CH}_{3}\right), 68.22(\mathrm{CH}), 116.74(\mathrm{CH}), 118.39(\mathrm{CH}), 118.65(\mathrm{C}), 126.16(2 \times \mathrm{CH}), 127.02(\mathrm{CH}), 128.45$ $(2 \times \mathrm{CH}), 131.24(\mathrm{CH}), 132.06(\mathrm{CH}), 143.65(\mathrm{C}), 160.92(\mathrm{C}), 163.27(\mathrm{CH})$. IR (nujol mull): 2354.8, 1627.9, 1576.5, 1278.1, 1149.6, 1081.5, 1015.6, 969.2, 851.6, 756.5, 700.3. MS(EI): $\mathrm{m} / z$ $225[\mathrm{M}]^{+}(64), 121$ (46), 105 (100). EI-HRMS: $m / z$. $[M]^{+}$calcd for $\mathrm{C}_{15} \mathrm{H}_{15} \mathrm{NO}, 225.1154$; found: 225.1154.

(S,E)-3-((1-Phenylethylimino)methyl)benzene-1,2-diol (3). 2,3-Dihydroxybenzaldehyde as a substrate. Orange solid (56\%). Purified by re-crystallization from ethanol. $\mathrm{Mp} 92-94^{\circ} \mathrm{C},[\alpha]_{\mathrm{D}}{ }^{20}=$ +266 (c 0.07, MeOH). ${ }^{1} \mathrm{H} \mathrm{NMR}\left(300 \mathrm{MHz}, \mathrm{CDCl}_{3}\right): \delta 1.69\left(\mathrm{~d}, J=6.6 \mathrm{~Hz}, 3 \mathrm{H}, \mathrm{CH}_{3}\right), 4.65(\mathrm{q}, J=$ 
$6.6 \mathrm{~Hz}, 1 \mathrm{H}, \mathrm{CH}), 6.66(\mathrm{t}, J=7.5 \mathrm{~Hz}, 1 \mathrm{H}, \mathrm{CH}$-aryl), $6.76(\mathrm{dd}, J=1.5 \mathrm{~Hz}, J=8.1 \mathrm{~Hz}, 1 \mathrm{H}, \mathrm{CH}-$ aryl), 6.96 (dd, $J=1.8 \mathrm{~Hz}, J=7.5 \mathrm{~Hz}, 1 \mathrm{H}, \mathrm{CH}$-aryl), 7.27-7.42 (m, 5H, CH-aryl), 8.26 (s, 1H, $\mathrm{HC}=\mathrm{N}$ ), 13.56 (br s, 2H, 2×OH). $\left.{ }^{13} \mathrm{C} \mathrm{NMR} \mathrm{(50.3} \mathrm{MHz,} \mathrm{CDCl}_{3}\right): \delta 24.23\left(\mathrm{CH}_{3}\right), 65.96(\mathrm{CH})$, $116.74(\mathrm{CH}), 116.37(\mathrm{CH}), 116.71(\mathrm{C}), 117.38(\mathrm{CH}), 122.08(\mathrm{CH}), 126.36(2 \times \mathrm{CH}), 127.66(\mathrm{CH})$, $128.87(2 \times \mathrm{CH}), 142.72(\mathrm{C}), 146.03(\mathrm{C}), 153.78(\mathrm{C}), 163.25(\mathrm{CH})$. IR (nujol mull): 3160.6, 1635.9, 1197.6, 1018.7, 858.2, 743.9, 696.4. MS(EI): $m / z 241[\mathrm{M}]^{+}(54), 137$ (55), 105 (100). EIHRMS: $m / z[\mathrm{M}]^{+}$calcd for $\mathrm{C}_{15} \mathrm{H}_{15} \mathrm{NO}_{2}, 241.1103$; found: 241.1099 .

(S,E)-2,4-Di-tert-butyl-6-((1-phenylethylimino)methyl)phenol

(4). 3,5-Di-t-butyl-2-

hydroxybenzaldehyde as a substrate. Yellow solid (79\%). Purified by re-crystallization from methanol. Mp 84-85 ${ }^{\circ}$, (lit. $\left.{ }^{7} 93-94^{\circ} \mathrm{C}\right),[\alpha]_{\mathrm{D}}{ }^{20}=+103(c 0.314, \mathrm{MeOH})\left(\right.$ lit. $^{7}[\alpha]^{20} \mathrm{D}=+119.6$ (c 0.726, $\left.\mathrm{CHCl}_{3}\right)$ ). ${ }^{1} \mathrm{H} \mathrm{NMR}\left(300 \mathrm{MHz}, \mathrm{CDCl}_{3}\right): \delta 1.33\left(\mathrm{~s}, 9 \mathrm{H}, 3 \times \mathrm{CH}_{3}: \mathrm{t}-\mathrm{Bu}\right), 1.49\left(\mathrm{~s}, 9 \mathrm{H}, 3 \times \mathrm{CH}_{3}\right.$ : t-Bu), $1.66\left(\mathrm{~d}, J=6.9 \mathrm{~Hz}, 3 \mathrm{H}, \mathrm{CH}_{3}\right), 4.56(\mathrm{q}, J=6.9 \mathrm{~Hz}, 1 \mathrm{H}, \mathrm{CH}), 7.11(\mathrm{~d}, J=2.4 \mathrm{~Hz}, 1 \mathrm{H}, \mathrm{CH}-$ aryl), 7.24-7.43 (m, 7H, CH-aryl), $8.45(\mathrm{~s}, 1 \mathrm{H}, \mathrm{HC}=\mathrm{N}), 13.84$ (br s, $1 \mathrm{H}, \mathrm{OH}) .{ }^{13} \mathrm{C}$ NMR $(50.3$ $\left.\mathrm{MHz}, \mathrm{CDCl}_{3}\right): \delta 24.88\left(\mathrm{CH}_{3}\right), 29.49\left(3 \times \mathrm{CH}_{3}\right), 31.51\left(3 \times \mathrm{CH}_{3}\right), 34.11(\mathrm{C}), 35.04(\mathrm{C}), 68.48(\mathrm{CH})$, $117.98(\mathrm{C}), 126.01(\mathrm{CH}), 126.51(2 \times \mathrm{CH}), 126.91(\mathrm{CH}), 127.14(\mathrm{CH}), 128.60(2 \times \mathrm{CH}), 136.68$ (C), 140.08 (C), 144.09 (C), 158.04 (C), 164.59 (CH). IR (nujol mull): 1629.4, 1540.2, 1362.0, 1272.2, 1250.3, 1202.8, 1173.4, 1076.1, 1026.1, 976.8, 879.1, 828.7, 764.1, 703.3. MS(EI): $\mathrm{m} / z$

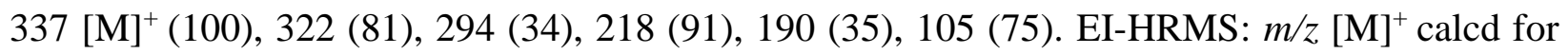
$\mathrm{C}_{23} \mathrm{H}_{31} \mathrm{NO}$, 337.2406; found: 337.2397.

\section{(S,E)-2-Methyl-6-((1-phenylethylimino)methyl)phenol}

(5).

2-Hydroxy-3methylobenzaldehyde as a substrate. Yellow oil (77\%). Purified by distillation under reduced pressure. Bp $156-158^{\circ} \mathrm{C} / 1$ Torr, $[\alpha]_{\mathrm{D}}{ }^{20}=+223(c 0.89, \mathrm{MeOH}) .{ }^{1} \mathrm{H} \mathrm{NMR}\left(300 \mathrm{MHz}, \mathrm{CDCl}_{3}\right): \delta$ $1.64\left(\mathrm{~d}, J=6.6 \mathrm{~Hz}, 3 \mathrm{H}, \mathrm{CH}_{3}\right), 2.30\left(\mathrm{~s}, 3 \mathrm{H}, \mathrm{CH}_{3}\right), 4.56(\mathrm{q}, J=6.6 \mathrm{~Hz}, 1 \mathrm{H}, \mathrm{CH}), 6.78(\mathrm{t}, J=7.5$ $\mathrm{Hz}, 1 \mathrm{H}, \mathrm{CH}$-aryl), 7.11 (dd, $J=1.5 \mathrm{~Hz}, J=7.5 \mathrm{~Hz}, 1 \mathrm{H}, \mathrm{CH}$-aryl), 7.17-7.41 (m, 6H, CH-aryl), $8.41(\mathrm{~s}, 1 \mathrm{H}, \mathrm{HC}=\mathrm{N}), 13.82$ (br s, $1 \mathrm{H}, \mathrm{OH}) .{ }^{13} \mathrm{C} \mathrm{NMR}\left(50.3 \mathrm{MHz}, \mathrm{CDCl}_{3}\right): \delta 15.43\left(\mathrm{CH}_{3}\right), 24.97$ $\left(\mathrm{CH}_{3}\right), 68.39(\mathrm{CH}), 117.98(\mathrm{C}), 118.09(\mathrm{CH}), 125.82(\mathrm{C}), 126.31(2 \times \mathrm{CH}), 127.14(\mathrm{CH}), 128.59$ $(2 \times \mathrm{CH}), 129.01(\mathrm{CH}), 133.21(\mathrm{CH}), 143.87(\mathrm{C}), 159.31(\mathrm{C}), 163.55(\mathrm{CH})$. IR (neat): 2972.2, 2867.0, 1626.9, 1491.5, 1452.1, 1308.2, 1269.6, 1123.8, 1084.5, 1033.4, 975.7, 910.5, 846.2, 747.9, 699.2. MS(EI): $m / z 239$ [M] $^{+}$(78), 135 (76), 105 (100). EI-HRMS: $m / z[\mathrm{M}]^{+}$calcd for $\mathrm{C}_{16} \mathrm{H}_{17} \mathrm{NO}, 239.1310$; found: 239.1301.

(S,E)-2-tert-butyl-4-methyl-6-((1-phenylethylimino)methyl)phenol (6). 3-tert-Butylo-2hydroxy-5-methylobenzaldehyde as a substrate. Yellow oil (61\%). Purified by distillation under reduced pressure. Bp $172-174^{\circ} \mathrm{C} / 1$ Torr, $[\alpha]_{\mathrm{D}}{ }^{20}=+147(c 0.89, \mathrm{MeOH}) .{ }^{1} \mathrm{H}$ NMR $(200 \mathrm{MHz}$, $\left.\mathrm{CDCl}_{3}\right): \delta 1.44\left(\mathrm{~s}, 3 \mathrm{H}, 3 \times \mathrm{CH}_{3}\right), 1.64\left(\mathrm{~d}, J=6.8 \mathrm{~Hz}, 3 \mathrm{H}, \mathrm{CH}_{3}\right), 2.28\left(\mathrm{~s}, 3 \mathrm{H}, \mathrm{CH}_{3}\right), 4.56(\mathrm{q}, J=6.8$ $\mathrm{Hz}, 1 \mathrm{H}, \mathrm{CH}), 6.78$ (d, J=2.2 Hz, 1H, CH-aryl), 7.12 (d, $J=1.8 \mathrm{~Hz}, 1 \mathrm{H}, \mathrm{CH}$-aryl), 7.25-7.40 (m, $6 \mathrm{H}, \mathrm{CH}-\operatorname{aryl}), 8.36$ (s, $1 \mathrm{H}, \mathrm{HC}=\mathrm{N}), 13.74(\mathrm{br} \mathrm{s}, 1 \mathrm{H}, \mathrm{OH}) \cdot{ }^{13} \mathrm{C} \mathrm{NMR}\left(75.5 \mathrm{MHz}, \mathrm{CDCl}_{3}\right): \delta 20.63$ $\left(\mathrm{CH}_{3}\right), 24.99\left(\mathrm{CH}_{3}\right), 29.41\left(3 \times \mathrm{CH}_{3}\right), 34.71(\mathrm{C}), 68.56(\mathrm{CH}), 118.42(\mathrm{C}), 126.50(2 \times \mathrm{CH}), 127.15$ $(\mathrm{CH}), 127.16(\mathrm{C}), 128.61(2 \times \mathrm{CH}), 129.63(\mathrm{CH}), 130.45(\mathrm{CH}), 137.05(\mathrm{C}), 144.01(\mathrm{C}), 158.03$ (C), 164.17 (CH). IR (neat): 2959.0, 2864.9, 1628.5, 1597.7, 1441.2, 1389.8, 1376.7, 1318.2, $1266.4,1211.0,1165.2,1121.6,1084.1,1030.1,975.5,909.2,862.3,789.8,761.2$, 698.9. 
MS(EI): m/z $295[\mathrm{M}]^{+}$(93), 280 (30), 252 (33), 190 (29), 176 (71), 148 (50), 105 (100). EIHRMS: $m / z$ [M] $]^{+}$calcd for $\mathrm{C}_{20} \mathrm{H}_{25} \mathrm{NO}, 295.1936$; found: 295.1932.

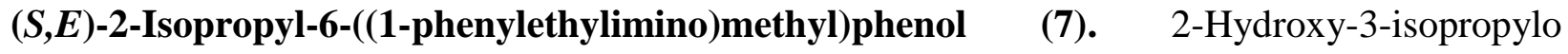
benzaldehyde as a substrate. Yellow oil (71\%). Purified by distillation under reduced pressure. Bp 176- $178^{\circ} \mathrm{C} / 1$ Torr, $[\alpha]_{\mathrm{D}}{ }^{20}=+206(c 1.39, \mathrm{MeOH}) .{ }^{1} \mathrm{H} \mathrm{NMR}\left(300 \mathrm{MHz}, \mathrm{CDCl}_{3}\right): \delta 1.24(\mathrm{~d}, J$ $=3.6 \mathrm{~Hz}, 3 \mathrm{H}, \mathrm{CH}_{3}$-iso-propyl), 1.28 (d, $J=3.6 \mathrm{~Hz}, 3 \mathrm{H}, \mathrm{CH}_{3}$-iso-propyl), 1.64 (d, J=6.6 Hz, 3H, $\mathrm{CH}_{3}$ ), 3.42 (sept, $J=6.9 \mathrm{~Hz}, 1 \mathrm{H}, \mathrm{CH}$-iso-propyl), 4.55 (q, $J=6.6 \mathrm{~Hz}, 1 \mathrm{H}, \mathrm{CH}$ ), 6.85 (t, $J=5.1$ $\mathrm{Hz}, 1 \mathrm{H}, \mathrm{CH}$-aryl), 7.11 (dd, $J=1.5 \mathrm{~Hz}, J=7.7 \mathrm{~Hz}, 1 \mathrm{H}, \mathrm{CH}$-aryl), 7.24-7.41 (m, 6H, CH-aryl), $8.42(\mathrm{~s}, 1 \mathrm{H}, \mathrm{HC}=\mathrm{N}), 13.88(\mathrm{br} \mathrm{s}, 1 \mathrm{H}, \mathrm{OH}) .{ }^{13} \mathrm{C} \mathrm{NMR}\left(50.3 \mathrm{MHz}, \mathrm{CDCl}_{3}\right): \delta 22.41\left(\mathrm{CH}_{3}\right), 22.49$ $\left(\mathrm{CH}_{3}\right), 24.96\left(\mathrm{CH}_{3}\right), 26.35(\mathrm{CH}), 68.44(\mathrm{CH}), 118.16(\mathrm{C}), 118.30(\mathrm{CH}), 126.37(2 \times \mathrm{CH}), 127.16$ $(\mathrm{CH}), 128.60(2 \times \mathrm{CH}), 128.60(\mathrm{CH}), 128.94(\mathrm{CH}), 136.22(\mathrm{C}), 143.89(\mathrm{C}), 158.46(\mathrm{C}), 163.79$ (CH). IR (neat): 3061.3, 2963.7, 2868.8, 2659.6, 1948.7, 1871.9, 1808.1, 1628.0, 1492.8, 1440.3, 1381.9, 1303.4, 1263.4, 1234.0, 1151.2, 1123.9, 1083.3, 1050.6, 1017.6, 976.4, 911.0, 879.7, 751.9, 699.1, 637.9. MS(EI): $\mathrm{m} / z 267[\mathrm{M}]^{+}$(44), 162 (100), 148 (27), 105 (66). EI-HRMS: $\mathrm{m} / z$ $[\mathrm{M}]^{+}$calcd for $\mathrm{C}_{18} \mathrm{H}_{21} \mathrm{NO}, 267.1623$; found: 267.1612 .

(S,E)-1-((1-Phenylethylimino)methyl)naphthalen-2-ol (8). 2-Hydroxy-1-naphthaldehyde as a substrate. Yellow solid (46\%). Purified by re-crystallization from hexane-ethyl acetate $(1: 1, \mathrm{v} / \mathrm{v})$. Mp $112-113^{\circ} \mathrm{C}$ (lit. $\left.{ }^{6} 104-108^{\circ} \mathrm{C}\right),[\alpha]_{\mathrm{D}}{ }^{20}=+193(c 0.34, \mathrm{MeOH})\left(\right.$ lit. $^{6}[\alpha]^{20}{ }_{\mathrm{D}}=+114.87$ (c 0.04, $\left.\mathrm{CH}_{2} \mathrm{Cl}_{2}\right)$ ). ${ }^{1} \mathrm{H} \mathrm{NMR}\left(300 \mathrm{MHz}, \mathrm{CDCl}_{3}\right): \delta 1.75\left(\mathrm{~d}, J=6.6 \mathrm{~Hz}, 3 \mathrm{H}, \mathrm{CH}_{3}\right), 4.77(\mathrm{q}, J=6.6 \mathrm{~Hz}, 1 \mathrm{H}$, $\mathrm{CH}), 6.98(\mathrm{~d}, J=9.3 \mathrm{~Hz}, 1 \mathrm{H}, \mathrm{CH}$-aryl), 7.21-7.45 (m, 7H, CH-aryl), 7.62 (d, $J=9.3 \mathrm{~Hz}, 1 \mathrm{H}$, CH-aryl), 7.71 (d, $J=9.3 \mathrm{~Hz}, 1 \mathrm{H}, \mathrm{CH}$-aryl), 7.82 (d, $J=8.4 \mathrm{~Hz}, 1 \mathrm{H}, \mathrm{CH}$-aryl), 8.85 (s, 1H, $\mathrm{HC}=\mathrm{N}$ ), 14.96 (br s, 1H, OH). ${ }^{13} \mathrm{C} \mathrm{NMR}\left(50.3 \mathrm{MHz}, \mathrm{CDCl}_{3}\right): \delta 24.18\left(\mathrm{CH}_{3}\right), 63.32(\mathrm{CH}), 107.08$ $(\mathrm{C}), 118.02(\mathrm{CH}), 122.78(\mathrm{CH}), 123.90(\mathrm{CH}), 126.25(2 \times \mathrm{CH}), 126.50(\mathrm{C}), 127.74(\mathrm{CH}), 127.77$ $(\mathrm{CH}), 128.92(2 \times \mathrm{CH}), 129.17(\mathrm{CH}), 133.54(\mathrm{C}), 136.65(\mathrm{CH}), 142.51(\mathrm{C}), 158.88(\mathrm{CH}), 173.85$ (C). IR (nujol mull): 1610.2, 1537.8, 1185.7, 1106.5, 1067.5, 987.5, 863.5, 832.8, 739.7, 699.4. MS(EI): $m / z 275[\mathrm{M}]^{+}$(100), 170 (79), 105 (85). EI-HRMS: $m / z[\mathrm{M}]^{+}$calcd for $\mathrm{C}_{19} \mathrm{H}_{17} \mathrm{NO}$, 275.1310; found: 275.1306 .

(S,E)-4-Bromo-2-((1-phenylethylimino)methyl)phenol (9). 5-Bromo-2-hydroxybenzaldehyde as a substrate. Yellow solid (99\%). Purified by re-crystallization from hexane-ethyl acetate $(1: 2, \mathrm{v} / \mathrm{v}) . \mathrm{Mp} 131-132^{\circ} \mathrm{C}$ (lit. $\left.{ }^{17} 130-132^{\circ} \mathrm{C}\right),[\alpha]_{\mathrm{D}}{ }^{20}=+41(c 0.24, \mathrm{MeOH})\left(\right.$ lit. $^{17} R$ enantiomer: $\left.[\alpha]^{20}{ }_{\mathrm{D}}=-54(\mathrm{c} 0.40, \mathrm{EtOH})\right) .{ }^{1} \mathrm{H} \mathrm{NMR}\left(200 \mathrm{MHz}, \mathrm{CDCl}_{3}\right): \delta 1.65(\mathrm{~d}, J=6.6 \mathrm{~Hz}$, $\left.3 \mathrm{H}, \mathrm{CH}_{3}\right), 4.58(\mathrm{q}, J=6.6 \mathrm{~Hz}, 1 \mathrm{H}, \mathrm{CH}), 6.95$ (d, $J=8.4 \mathrm{~Hz}, 1 \mathrm{H}, \mathrm{CH}$-aryl), 7.10-7.23 (m, 7H, $\mathrm{CH}$-aryl), $8.32(\mathrm{~s}, 1 \mathrm{H}, \mathrm{HC}=\mathrm{N}), 13.56($ br s, $1 \mathrm{H}, \mathrm{OH}) .{ }^{13} \mathrm{C} \mathrm{NMR}\left(75.5 \mathrm{MHz}, \mathrm{CDCl}_{3}\right): \delta 24.68$ $\left(\mathrm{CH}_{3}\right), 68.36(\mathrm{CH}), 109.95(\mathrm{C}), 118.95(\mathrm{CH}), 120.14(\mathrm{C}), 126.36(2 \times \mathrm{CH}), 127.39(\mathrm{CH}), 128.71$ $(2 \times \mathrm{CH}), 132.44(\mathrm{CH}), 134.84(\mathrm{CH}), 143.25(\mathrm{C}), 160.11(\mathrm{C}), 162.15(\mathrm{CH})$. IR (nujol mull): 2853.4, 2356.0, 1878.2, 1766.3, 1633.1, 1601.4, 1556.6, 1276.0, 1180.7, 1087.6, 1017.3, 966.1, 914.4, 889.5, 819.8, 767.4, 699.4. MS(EI): m/z 303 [M] ${ }^{+}(29), 198$ (29), 135 (38), 105 (100). EIHRMS: $m / z[\mathrm{M}]^{+}$calcd for $\mathrm{C}_{15} \mathrm{H}_{14} \mathrm{BrNO}, 303.0259$; found: 303.0255 . 


\section{General procedure for asymmetric addition of $\mathrm{Et}_{2} \mathrm{Zn}$ to aldehydes}

Diethylzinc ( $2 \mathrm{mmol}, 2 \mathrm{ml}, 1 \mathrm{M}$ solution in hexanes) was added to a solution of chiral Schiff base $(20 \mathrm{~mol} \%)$ in dry toluene $(5 \mathrm{ml})$ at appropriate temperature $\left(0^{\circ} \mathrm{C},-20^{\circ} \mathrm{C}\right.$ or $-70^{\circ} \mathrm{C}$-Table 1$)$ in an atmosphere of $\mathrm{N}_{2}$. After $1 \mathrm{~h}$ aldehyde ( $1 \mathrm{mmol}, 1 \mathrm{M}$ solution in dry toluene, $1 \mathrm{ml}$ ) was added and the reaction mixture was turned to room temperature. The mixture was stirred for appropriate time (Tables 4 and 5) and then was quenched with the saturated solution of ammonium chloride $(5 \mathrm{ml})$ and was extracted with ethyl acetate $(3 \times 10 \mathrm{ml})$. The organic solution was washed with brine, dried over anhydrous $\mathrm{MgSO}_{4}$ and gravity filtered. Then, the solvent was stripped to obtain enantiomerically enriched 1-phenyl-1-propanol. Crude samples were analyzed by GC method using ZB-5 capillary column to determine the amount of by-product (appropriate benzyl alcohol). When necessary, the crude product was purified by the column chromatography using appropriate eluents (usually hexane:ethyl acetate $=5: 1 \mathrm{v} / \mathrm{v}$ ). The e.e.'s were determined with HPLC using ODH-Chiralcel column or GC analysis using $\beta$-Dex capillary column. Yields were determined via GC analysis using ZB-5 capillary column or by isolation of the product (Tables 2 and 3).

\section{References}

1. (a) Gennari, C.; Piarulli, U. Chem. Rev. 2003, 103, 3071. (b) Baleizão, C.; Garcia, H. Chem. Rev. 2006, 106, 3987. (c) North, M.; Usanov, D. L.; Young, C. Chem. Rev. 2008, 108, 5146.

2. Manrao, M. R.; Kohli, S. J. Indian Chem. Soc. 1986, 63, 348.

3. Grodziskie Zaklady Farmaceutyczne 'Polfa', Neth. Appl. 6,415,155/1966; Chem. Abstr. 1967, 67, 3094c.

4. Grodziskie Zaklady Farmaceutyczne 'Polfa' (by Chylinska, J.; Janowiec, M.; Urbanski, T. and Venulet J.), Pol. P. 48,464/1965; Chem. Abstr. 1966, 64, 15895a.

5. Kovalenko, F. P. Deposited Doc., 1978, VINITI 3276-78; Chem. Abstr. 1980, 92, 141168x.

6. Iglesias, A. L.; Aguirre, G.; Somanathan, R.; Parra-Hake, M. Polyhedron 2004, 23, 3051.

7. Zhou, X. G.; Huang, J. S.; Ko, P. H.; Cheung, K. K.; Che, C. M. J. Chem. Soc., Dalton Trans. 1999, 3303.

8. Kumar, A.; Agarwal, M.; Singh, A. K.; Butcher, R. J. Inorg. Chim. Acta 2009, 362, 3208.

9. Fache, F.; Schulz, E.; Tommasino, M. L.; Lemaire, M. Chem. Rev. 2000, 100, 2159.

10. (a) Tanaka, T.; Yasuda, Y.; Hayashi, M. J. Org. Chem. 2006, 71, 7091. (b) Jiang, F.-Y.; Liu, B.; Dong, Z.-B.; Li, J.-S. J. Organomet. Chem. 2007, 69, 4377. (c) Jaworska, M.; Łączkowski K. Z.; Wełniak, M.; Welke, M.; Wojtczak, A. Appl. Catal. A 2009, 357, 150. (d) Sigman, M. S.; Jacobsen, E. N. J. Am. Chem. Soc. 1998, 120, 5315. (e) Hayashi, M.; Miyamoto, Y.; Inoue, T.; Oguni, N. J. Org. Chem. 1993, 58, 1515.

11. Cimarelli, C.; Palmieri, G.; Volpini, E. Org. Prep. Proced. Int. 2001, 33, 369.

12. Yang, X.-F.; Wang, Z.-H.; Koshizawa, T.; Yasutake, M.; Zhang, G.-Y.; Hirose, T. Tetrahedron: Asymmetry 2007, 18, 1257. 
13. Landis, C.; Halpern, J. J. Am. Chem. Soc. 1987, 109, 1746.

14. Park, S. B.; Murata, K.; Matsumoto, H.; Nishiyama, H. Tetrahedron: Asymmetry 1995, 6, 2487.

15. Zhang, H.; Xue, F.; Mak, T. C. W.; Chan, K. S. J. Org. Chem. 1996, 61, 8002.

16. Kündig, E. P.; Botuha, C.; Lemercier, G.; Romanens, P.; Saudan, L.; Thibault, S. Helv. Chim. Acta 2004, 87, 561.

17. Smith, H. E.; Cook, S. L.; Warren, Jr., M. E. J. Org. Chem. 1964, $29,2265$.

18. Barbara, P. F.; Brus, L. E.; Rentzepis, P. M. J. Am. Chem. Soc. 1980, 102, 5631.

19. Zugazagoitia, J. S.; Maya, M.; Damián-Zea, C.; Navarro, P.; Beltrán, H. I.; Peon, J. J. Phys. Chem. A 2010, 114, 704.

20. Jeffrey, G. A. An Introduction to Hydrogen Bonding, Oxford University Press: New York, 1997.

21. Allen, F. H. Acta Cryst. B 2002, 58, 380.

22. Flack, H. D. Acta Cryst. A 1983, 39, 876.

23. Akitsu, T.; Einaga, Y. Acta Cryst. E 2006, 62, o4315.

24. Santoni, G.; Rehder, D. J. Inorg. Biochem. 2004, 98, 758.

25. Lindeman, S. V.; Filippova, T. V.; Kravcheni, S. G.; Shklover, V. E.; Struchkov, Y. T.; Potapov, V. M. Kristallografiya 1987, 32, 1410.

26. Kitamura, M.; Okada, S.; Suga, S.; Noyori, R. J. Am. Chem. Soc. 1989, 11, 4028.

27. Tanyeli, C.; Odabaş, S.; Erdem, M.; Çakır, E.; Keskin, E. Tetrahedron: Asymmetry 2007, 28, 2349.

28. Chen, Y.-J.; Lin, R.-X.; Chen, C. Tetrahedron: Asymmetry 2004, 15, 3561.

29. Bauer, T.; Gajewiak, J. Tetrahedron: Asymmetry 2005, 16, 851.

30. Danilova, T. I.; Rozenberg, V. I.; Sergeeva, E. V.; Starikova, Z. A.; Bräse, S. Tetrahedron: Asymmetry 2003, 14, 2013.

31. ArgusLab 4.0.1, Thompson, M. A.; Planaria Software LLC, Seattle, WA, http://www.arguslab.com.

32. Rasmussen, T.; Norrby, P.-O. J. Am. Chem. Soc. 2003, 125, 5130.

33. Palmieri, G. Tetrahedron: Asymmetry 2000, 11, 3361.

34. Parrott II, R. W.; Dore, D. D.; Chandrashekar, S. P.; Bentley, J. T.; Morgan, B. S.; Hitchcock, S. R. Tetrahedron: Asymmetry 2008, 19, 607.

35. Tanaka, T.; Yasuda, Y.; Hayashi, M. J. Org. Chem. 2006, 71, 7091.

36. (a) Jacobsen, E. N.; Zhang, W.; Guler, M. L. J. Am. Chem. Soc. 1991, 113, 6703. (b) Park, S.-B.; Murata, K.; Matsumoto, H.; Nishiyama, H. Tetrahedron: Asymmetry 1995, 6, 2487. (c) Corey, E. J.; Helal, C. J. Tetrahedron Lett. 1995, 36, 9153. (d) Schnyder, A.; Hintermann, L.; Togni, A. Angew. Chem., Int. Ed. Engl. 1995, 34, 931. (e) Yang, X.-F.; Hirose, T.; Zhang, G.-Y. Tetrahedron: Asymmetry 2007, 18, 2668. (f) Błocka, E.; Jaworska, M.; Kozakiewicz, A.; Wełniak, M.; Wojtczak, A. Tetrahedron: Asymmetry 2010, 21, 571. 
37. Jaworska, M.; Hrynczyszyn, P. B.; Wełniak, M.; Wojtczak, A.; Nowicka, K.; Krasiński, G.; Kassassir, H.; Ciesielski, W.; Potrzebowski, M. J. J. Phys. Chem. A, 2010, 114, 1252212530.

38. Hansen, P. E.; Rozwadowski, Z.; Dziembowska, T. Curr. Org. Chem. 2009, 13, 194.

39. Nelson, H. S. N. Engl. J. Med. 1995, 333, 499.

40. CrysAlis CCD171 and RED171 Package of Programs, Oxford Diffraction, 2000.

41. Sheldrick, G. M. SHELXS97 and SHELXL97, University of Goettingen, Germany, 1997.

42. Larrow, J. F.; Jacobsen, E. N.; Gao, Y.; Hong, Y.; Nie, X.; Zepp, C. M. J. Org. Chem. 1994, 59, 1939.

43. Brenner, M.; Huber, W. Helv. Chim. Acta 1953, 36, 1109. 